\title{
Biogeochemical characterization of suspended particulate matter in the Columbia River estuary
}

\author{
F. G. Prahl*, L. F. Small, B. Eversmeyer \\ College of Oceanic and Atmospheric Sciences, Oregon State University, Corvallis, Oregon 97331, USA
}

\begin{abstract}
In order to understand what controls the composition of suspended particulate material (SPM) in estuarine turbidity maxima (ETM), a set of SPM samples collected in the Columbia River and estuary (northwestern USA) during 3 seasons (fall 1990, summer 1991, spring 1992) was analyzed for detrital mineral (Min), total organic matter [OM, as $2 \times$ particulate organic carbon (POC)], biogenic silica (BSi), chlorophyll $a, \delta^{13} \mathrm{C}$, and lignin. In most samples, Mm, OM and BSi collectively accounted for $100 \%$ of total SPM mass, although their relative importance changed seasonally. The ETM was a trap for organic matter durng all 3 seasons, which can explann the intense microbial activity and microcrustacean grazing observed previously. The organic matter was particularly rich in chlorophyll a in late spring to early summer The source of this seasonal enrichment was mainly riverne phytoplankton. The organic matter contribution to ETM from the ocean was mınor compared to the river, but apparently not negligible. Despite large seasonal variations in chlorophyll content, the $\delta^{17} \mathrm{C}$ of POC concentrated in ETM remained nearly constant between -26 and $-25.5 \%$ Vascular plant debris, as depicted by lignin phenol content, always comprised a minor fraction of the organic matter in ETM. although ETM had higher lignin levels than the OM of surrounding waters. Intertidal mudflats are $1 t$ not an additional source of organic matter at least an important site for transforming riverine organic matter that is ultimately concentrated in ETM
\end{abstract}

KEY WORDS: Columbia River estuary - Estuanne turbıdıty maxima (ETM) - Mudflats - Suspended particulate material (SPM) Particulate organic carbon (POC) Chlorophyll Lignın Aluminum Manganese

\section{INTRODUCTION}

The Columbia-Snake River watershed is the second largest in the United States. The drainage basin of $660480 \mathrm{~km}^{2}$ extends into 7 states and 2 Canadian provinces (Simenstad et al. 1990). The system culminates in the Columbia River estuary, which occupies a drowned river valley cut into Tertiary volcanic and sedimentary bedrock. Hence, it is narrow relative to its length, with only a few shallow, wide-mouthed bays and no substantial tributary rivers into the main stem (Fig. 1). There are 2 main channels in the estuary. The South Channel extends continuously from the river through the estuary and represents the main shipping channel. The North Channel is an appendix blocked off at mid-estuary from direct upriver connection,

\footnotetext{
•E-mail:fprahi@oce.orst.edu
}

extending seaward along the north shore. Physical processes associated with tidal mixing of freshwater and saltwater (Geyer 1993) promote trapping and increased residence time of organic and inorganic particulate matter in both channels of the estuary (Jay et al. 1990, Reed \& Donovan 1994). The result is formation of estuarine turbidity maxima (ETM), transient sedimentary features common to many river-dominated estuaries throughout the world (Berner \& Berner 1996). Changes in position, intensity, and duration of ETM occur on interannual, seasonal, tidal monthly (neap/spring) and tidal daily (flood/ebb) time scales (Gelfenbaum 1983, Jay et al. 1990 and references therein), so that one broad region in each channel encompasses most of these transient sedimentary events (Fig. 1). High biological activity and major sedimentological transformations have been documented within Columbia River ETM and their immediate vicinity (Baross et al. 1994, Reed \& Donovan 1994, 
Fig. 1 Location of the Columbra River Basin in the Pacific Northwest (USA) and sites within the Columbia River and its estuary where suspended particulate material (SPM] was collected for this study (i.e. RM10, outflow from Baker Bay mudflats, Buoy 39, RM53). Broad regions of the estuary are identifjed in the lower panel where transient estuarine turbidity maxima (ETM) commonly occur
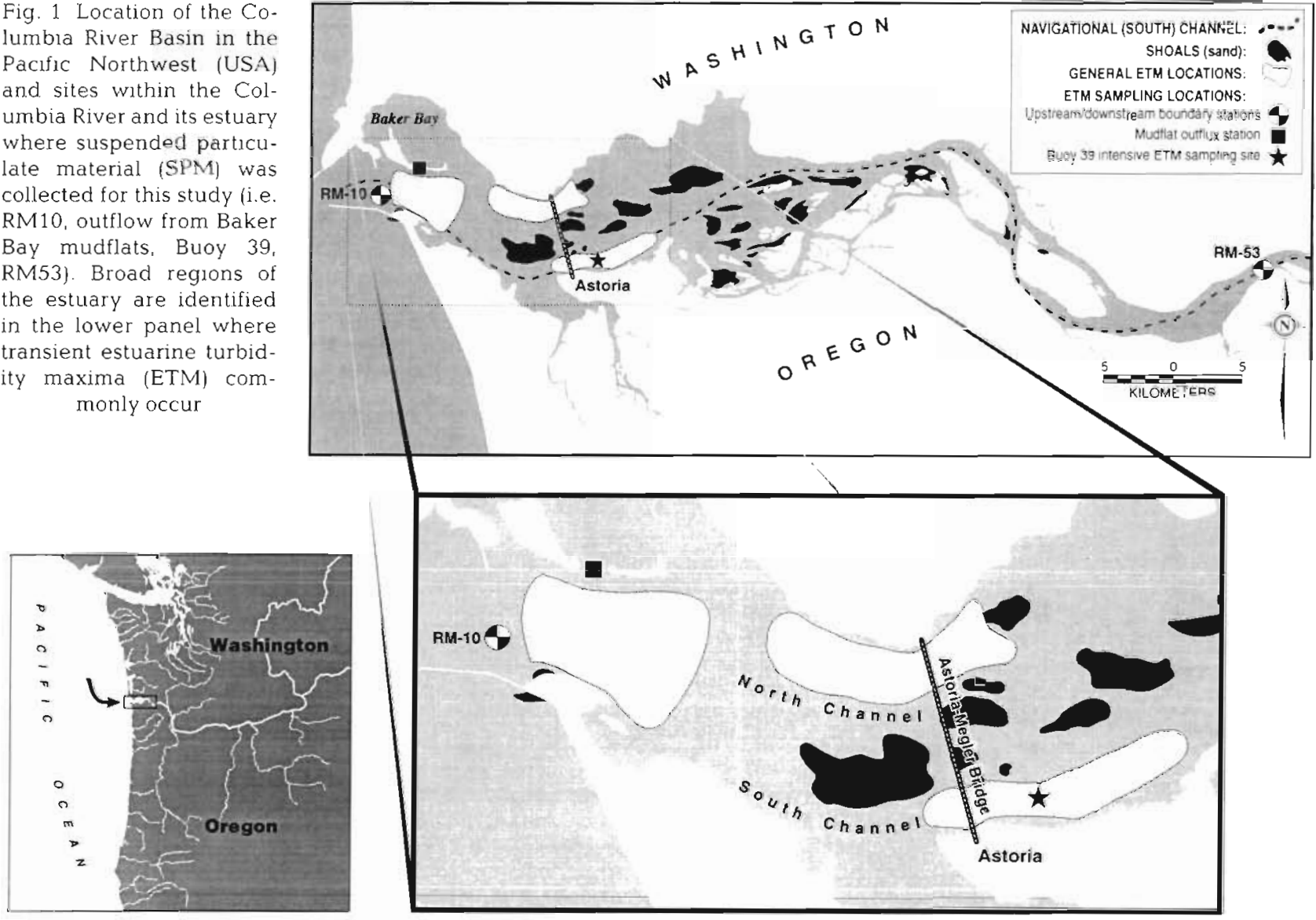

Simenstad et al. 1994a, Small \& Morgan 1994). For this reason, ETM regions are now viewed as a major biogeochemical interface linking the Columbia River watershed with the coastal northwest Pacific Ocean.

In earlier studies, the input of suspended particulate matter (SPM) and dissolved organic matter (DOM) to the estuary was thought to derive mainly from the Columbia River itself, and to a lesser extent from the coastal ocean (Dahm et al. 1981, Bristow et al. 1985, Small et al. 1990). However, in situ primary production, principally from phytoplankton, can add to the particulate organic matter in the estuary (Small et al. 1990), and recent evidence suggests that tidal runoff and erosion from intertidal mudflats are sometimes important contributors of DOM and SPM (Prahl \& Coble 1994). In the present study, we conducted a comprehensive chemical analysis of SPM in the Columbia River estuary, with specific emphasis on particles concentrated in ETM. Our objectives were to characterize the various sources contributing particles to ETM, and give an initial interpretation of the seasonal role that this transient sedimentary feature plays as a temporary trap and site for biological transformation of particles.

\section{METHODS}

In 3 different years (fall 1990, summer 1991, spring 1992), SPM samples were collected aboard the RV 'Robert Gordon Sproul' at Buoy 39, situated in the South Channel of the estuary within a region where prominent ETM events occur (Fig. 1). Additional SPM samples were collected on these cruises at sites located 53 river miles $(85 \mathrm{~km})$ upstream from the mouth of the estuary (RM53) and near the mouth of the estuary (RM10). These sites were chosen to gauge fluvial input to the estuary and to estimate exchange with the coastal ocean, respectively. Limited sampling on ebb tides at the entrance to Baker Bay in summer 1991 and spring 1992 was initiated to see if erosion from intertidal mudflats could be ruled out as an influence on the composition of SPM in the main estuary, particularly within ETM.

SPM samples from the various sites were collected every $2 \mathrm{~h}$ for $30 \mathrm{~h}$ at all sites except the entrance to Baker Bay where sampling was every half hour for $8 \mathrm{~h}$ beginning just before a greater ebb tide. Detailed CTD and optical backscatter (OBS, an in situ measure of 
Table 1. Percentage contribution ( $\pm 1 \sigma$ with number of samples given in parentheses) of detrital mineral ( $\%$ Min), organic matter (\% OM) and biogenic silica (\% BSi) to total mass for suspended particulate material (\% SPM) collected in surface waters, non-

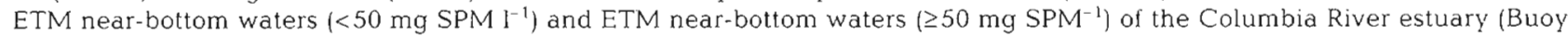
39) during 3 different sampling periods (fall 1990, summer 1991, spring 1992). \% Min, \% OM and \% BSi were estimated from measurements of total aluminum, total organic carbon and extractable silica as described in the text. -: no data

\begin{tabular}{|c|c|c|c|c|c|c|c|c|c|}
\hline & \multicolumn{3}{|c|}{ Fall 1990} & \multicolumn{3}{|c|}{ Summer 1991} & \multicolumn{3}{|c|}{ Spring 1992} \\
\hline & Surface & Non-ETM & ETM & Surface & Non-ETM & ETM & Surface & Non-ETM & ETM \\
\hline$\%$ Min & $\begin{array}{c}82 \pm 3.7 \\
(17)\end{array}$ & $\begin{array}{c}83 \pm 5.3 \\
(14)\end{array}$ & $\begin{array}{c}89 \pm 5.2 \\
\text { (3) }\end{array}$ & $\begin{array}{c}68 \pm 3.3 \\
\{21\}\end{array}$ & $\begin{array}{c}76 \pm 3.3 \\
(14)\end{array}$ & $\begin{array}{c}84 \pm 5.7 \\
(8)\end{array}$ & $\begin{array}{c}64 \pm 7.8 \\
(27)\end{array}$ & $\begin{array}{c}72 \pm 5.1 \\
(1.9)\end{array}$ & $\begin{array}{c}73 \pm 5.4 \\
(8)\end{array}$ \\
\hline$\% \mathrm{OM}$ & $\begin{array}{c}8 \pm 2.4 \\
(17)\end{array}$ & $\begin{array}{c}9 \pm 1.5 \\
(14)\end{array}$ & $\begin{array}{c}9 \pm 1.9 \\
(3)\end{array}$ & $\begin{array}{c}15 \pm 2.6 \\
(21)\end{array}$ & $\begin{array}{c}11 \pm 1.7 \\
(14)\end{array}$ & $\begin{array}{c}9 \pm 2.6 \\
(8)\end{array}$ & $\begin{array}{c}17 \pm 5.4 \\
(55)\end{array}$ & $\begin{array}{c}12 \pm 3.0 \\
(42)\end{array}$ & $\begin{array}{c}12 \pm 3.3 \\
(13)\end{array}$ \\
\hline$\% \mathrm{BSi}$ & $\begin{array}{c}12 \pm 3.4 \\
(7)\end{array}$ & $\begin{array}{c}9 \pm 2.3 \\
(7)\end{array}$ & - & $\begin{array}{c}18 \pm 2.9 \\
(6)\end{array}$ & $\begin{array}{c}12 \pm 2.4 \\
(3)\end{array}$ & $\begin{array}{c}6 \pm 1.2 \\
(3)\end{array}$ & $\begin{array}{c}19 \pm 4.5 \\
(27)\end{array}$ & $\begin{array}{c}16 \pm 3.3 \\
(19)\end{array}$ & $\begin{array}{c}13 \pm 2.3 \\
(8)\end{array}$ \\
\hline$\% \mathrm{SPM}$ & $102 \pm 5.6$ & $101 \pm 5.7$ & - & $101 \pm 5.1$ & $99 \pm 4.5$ & $99 \pm 6.3$ & $100 \pm 10.4$ & $100 \pm 7.2$ & $98 \pm 6.9$ \\
\hline
\end{tabular}

SPM concentration) measurements were also obtained in time series for each site at 2 to $4 \times$ higher frequency than for SPM sampling. Immediate shipboard conversion of CTD and OBS data into depth profiles for salinity, temperature and SPM concentration allowed prediction and visualization of ETM events in near-real time. A high-volume pump, with attached plastic hose for delivering water samples on deck, was deployed in the water providing 2 SPM samples per cast for chemical characterization - one from just below the surface and the other from $\sim 1 \mathrm{~m}$ above the sandy bottom.

Immediately on shipboard, SPM in water from a given pump cast was isolated by filtration onto various sized glass fiber and polycarbonate membrane filters and stored appropriately until analysis. The following particle attributes were determined: total SPM mass by gravimetric determination ( \pm 10 to $15 \%$ variability in replicate samples); total particulate organic carbon (POC) and nitrogen (PON) by CHN analyzer $( \pm 5$ to $10 \%)$; chlorophyll $a$ and pheopigment concentrations by fluorometry on acetone-extracted samples $( \pm 3$ to $8 \%$ ); total aluminum and manganese content by nondestructive instrumental neutron activation analysis [INAA $( \pm 5 \%)_{i}$ Collier (1991)]; lignin phenols $( \pm 10$ to $15 \%$ ) by the cupric oxide oxidation method of Hedges \& Ertel (1982), and $\delta^{13} \mathrm{C}$ analysis of POC by isotope ratio mass spectrometry $( \pm 0.1 \%$ ) with all values reported in per mil $(\%)$ relative to the primary calcium carbonate reference standard PeeDee Belemnite (Hayes 1983). Biogenic silica was also measured as dissolved silicate by spectrophotometry upon release by mild leaching with a weak solution of $\mathrm{Na}_{2} \mathrm{CO}_{3}$ (DeMaster 1981) from particles previously examined by INAA (replicate samples within 5 to $10 \%$ ). Not every SPM sample was analyzed for all particle attributes. Further description of the sampling procedures and analytical protocols is provided elsewhere (Prahl \& Coble 1994, Prahl et al. 1994, Simenstad et al.1994b, Small \& Morgan 1994).

\section{RESULTS}

\section{Bulk SPM composition}

Initially, we were interested to see if total mass for SPM, regardless of where or when it was collected in the river-estuary continuum, could be conservatively partitioned into components whose study would provide better understanding of suspended particle dynamics in the estuary. A 3-component model for percentage composition of total SPM mass (\% SPM) was defined operationally as:

$$
\% \mathrm{SPM}=\% \mathrm{Min}+\% \mathrm{OM}+\% \mathrm{BSi}
$$

where \% Min, \% OM and \% BSi are, respectively, weight percentages of detrital minerals, organic matter, and biogenic silica. \% Min was calculated as the weight percent aluminum in our SPM samples (\% Al) divided by the fractional crustal abundance of aluminum (0.082; Taylor 1964). \% OM was estimated by assuming that measured POC represented $50 \%$ of organic matter by weight (Rashid 1985). Because diatoms are dominant primary producers in the Columbia River and its estuary (Amspoker \& McIntire 1986, Lara-Lara et al. 1990a, Sullivan 1997), the biogenic silica component (\% BSi) was also recognized as a significant contributor to SPM. Mean percentages $( \pm 1 \sigma)$ for the 3 components of SPM were calculated for samples collected at surface and near bottom depths in the estuary in each of the 3 seasons (Table 1). As per Small \& Morgan (1994), near-bottom SPM was divided into non-ETM and ETM concentrations, with non-ETM concentrations defined as $<50 \mathrm{mg} \mathrm{SPM}^{-1}$ and ETM as $\geq 50 \mathrm{mg} \mathrm{SPM}^{-1}$. Detrital minerals, organic matter and biogenic silica always accounted for $100 \%( \pm 1 \sigma)$ of total SPM mass, regardless of the season or depth of collection in the estuarine water column (Table 1). Detrital minerals dominated SPM mass at all times (64 


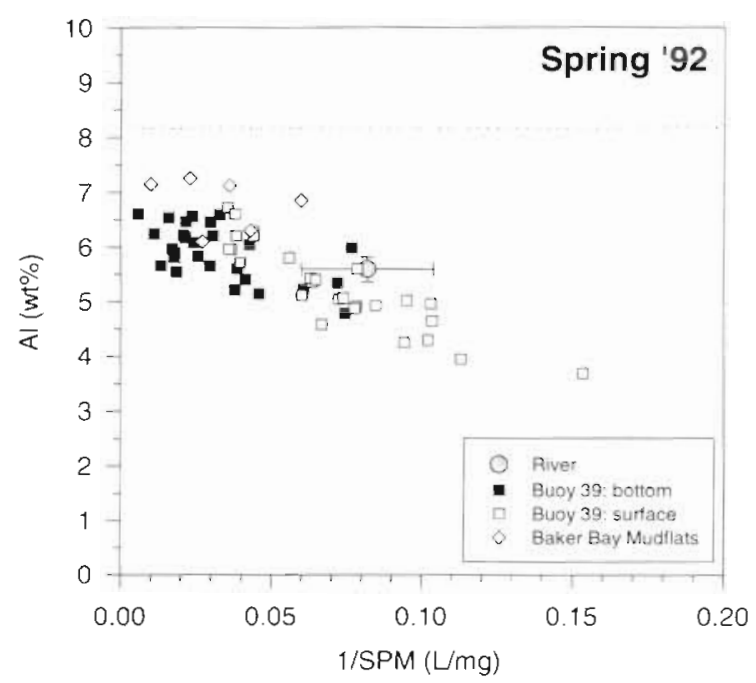

Fig. 2. Aluminum as a weight percentage of SPM (\% Al) plotted as a function of the reciprocal for suspended particulate matter concentration (1/SPM) in spring 1992. The trend of incrnasing \% Al with increasing SPM concentration (lower 1/SHM) indicates the increasing percentage contribution of detrital minerals as SPM concentration increases, at the expense of percentage contributions from organic matter and biogenic silica. Note that the highest $\% \mathrm{Al}$ values are associated with estuarine turbidity maxima (ETM), where ETM are operationally defined as $\geq 50 \mathrm{mg} \mathrm{SPM}^{-1}$ ( $1 / \mathrm{SPM}$ of 0.02$)$, indicated by the area on the plot to the left of the vertical dotted line). The horizontal dolted line depicts the average crustal abundance of $\mathrm{Al}(8.2 \%)$

to $89 \%$ ). However, percentages for detrital minerals were substantially less in spring (64 to $73 \%$ ) than in fall ( 82 to $89 \%$ ), with the lesser values in spring compensated by increased percentages of organic matter and biogenic silica. Generally, summer percentages (68 to $84 \%)$ were intermediate between those in spring and fall.

ETM always had the highest \% Min, on average, when compared to non-ETM and estuarine surface SPM (Table 1.). A plot of \% A in SPM versus 1/SPM further points up this feature (F.ig. 2). Weight \% $\mathrm{Al}$, as a surrogate for \% Min, increases as SPM concentration increases (1/SPM decreases), with highest values of both in ETM. Note that \% Al in ETM trends toward average crustal abundance of $\mathrm{Al}(8.2 \%)$, but does not reach it because organic matter and biogenic silica also contribute significantly to ETM composition in the Columbia Estuary. It should be noted here that we use the convention 1/SPM (with units of $1 \mathrm{mg}^{-1}$ ) in order to feature most effectively by graphic means particle mixing in the estuary (e.g. see Morris et al. 1987) In particular, using 1/SPM allows us to better focus on ETM as endmembers to mixing curves; e.g. in Fig. 2, $\% \mathrm{Al}$ values in ETM $(1 / \mathrm{SPM}<0.02)$ are easily visualized as endmembers of a linearized relationship .n- volving \% AI values from the river, mid-estuary, and mudflat runoff.

ETM had the lowest \% BSi, on average, when compared to surface and non-ETM values for the 2 seasons in which data were available (Table 1). \% BSi was positively correlated with \% OM through all seasons (Fig. 3), and on average these biologically derived terms were negatively correlated with \% Min (not illustrated). We interpret these correlations to indicate that the organic matter in the estuary is derived principally from primary production within the river-estuary system, and not linked to the source(s) of detrital minerals eroding into the system.

Mean percentages $( \pm 1 \sigma$ ) for each of the 3 SPM components were also calculated for the 3 presumed major sources of particles to ETM, namely the river, the intertidal mudflats and the coastal ocean (mouth of estuary) (Table 2). SPM from the river was most similar in bulk composition to that from estuarine surface waters, and least similar to that from ETM (Tables 1 \& 2). In summer, SPM eroding from intertidal mudflats bore almost identical percentage composition to particles in non-ETM bottom waters (Tables 1 \& 2). The mudflat compositional pattern cannot be generalized seasonally, however, as it did not apply in spring when SPM eroding off the mudflats appeared more detrital mineral-rich and organic matter-poor, on average, than SPM anywhere else in the system, including ETM

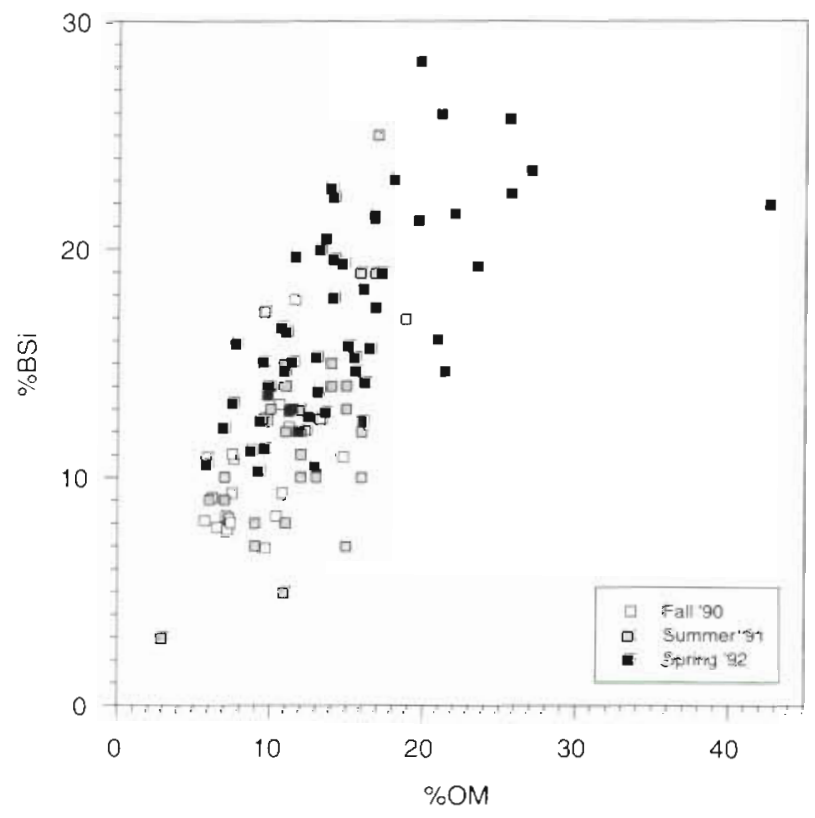

Fig. 3. Relationship between biogenic silica (\% BSi) and organic matter $(\%$ OM) fractions of SPM in the 3-component SPM model, highlighting the general seasonal trend but masking the differences among ETM, non-ETM and surface particles 
Table 2. Percentage contribution ( $\pm 1 \sigma$ with number of samples given in parentheses) of detrital mineral ( $\%$ Min), organic matter $(\% \mathrm{OM})$ and biogenic silica (\% BSi) to total mass for suspended particulate material (\% SPM) collected in the river (RM53), advecting near-bottom of mudflats at Baker Bay during ebb tides and near the mouth of the estuary (RM10) on both ebb and flood tides during 3 different sampling periods (fall 1990, summer 1991 and spring 1992). \% Min, \% OM and \% BSi were esti-

mated from measurements of total aluminum, total organic carbon and extractable silica as described in the text. -: no data

\begin{tabular}{|c|c|c|c|c|c|c|c|c|}
\hline & \multicolumn{3}{|c|}{ — Fall $1990-$} & \multirow{2}{*}{$\begin{array}{l}\text { Summer } 1991 \\
\text { Mudflats }\end{array}$} & \multirow[b]{2}{*}{ River } & \multirow{2}{*}{ Mudflats } & Spring 1992 & \multirow[b]{2}{*}{ Mouth (flood) } \\
\hline & River & Mouth (ebb) & Mouth (flood) & & & & Mouth (ebb) & \\
\hline$\% \mathrm{Min}$ & $\begin{array}{c}80 \pm 1.6 \\
(3)\end{array}$ & - & $\begin{array}{c}28 \pm 10.8 \\
(3)\end{array}$ & $\begin{array}{c}78 \pm 4.6 \\
(16)\end{array}$ & $\begin{array}{c}68 \pm 2.7 \\
\text { (11.) }\end{array}$ & $\begin{array}{c}85 \pm 4.7 \\
(6)\end{array}$ & $\begin{array}{l}73 \\
(1)\end{array}$ & $\begin{array}{l}45 \\
(2)\end{array}$ \\
\hline$\% \mathrm{OM}$ & $\begin{array}{c}12 \pm 0.8 \\
\text { (3) }\end{array}$ & $\begin{array}{c}15 \pm 4.6 \\
(6)\end{array}$ & $\begin{array}{c}35 \pm 8.8 \\
(3)\end{array}$ & $\begin{array}{c}12 \pm 1.8 \\
(16)\end{array}$ & $\begin{array}{c}14+1.7 \\
(11)\end{array}$ & $\begin{array}{c}8.3 \pm 1.8 \\
(6)\end{array}$ & $\begin{array}{c}13 \pm 6.8 \\
(8)\end{array}$ & $\begin{array}{c}13 \pm 7.6 \\
(7)\end{array}$ \\
\hline$\% \mathrm{BSi}$ & $\begin{array}{c}12 \pm 0.2 \\
\text { (3) }\end{array}$ & - & $\begin{array}{c}20 \pm 2.2 \\
\text { (3) }\end{array}$ & $\begin{array}{c}12 \pm 2.2 \\
(8)\end{array}$ & $\begin{array}{c}17 \pm 1.3 \\
(10)\end{array}$ & - & $\begin{array}{l}13 \\
\text { (1) }\end{array}$ & $\begin{array}{l}24 \\
(2)\end{array}$ \\
\hline$\%$ SPM & $104 \pm 0.8$ & - & 83 & $102 \pm 3.3$ & $99 \pm 0.7$ & - & 99 & 82 \\
\hline
\end{tabular}

(Tables 1 \& 2, Fig. 2). SPM composition near the mouth of the estuary (RM10) varied by tidal phase as well as by season (Table 2). On the flood tide, the 3-component model failed quite significantly to account for $100 \%$ of SPM composition. The apparent mass deficit was attributed to an improbably low assessment of $\%$ Min $(28 \%)$. We speculate that the detrital mineral fraction entering the estuary mouth on flood tides was enriched in quartz-rich sand, thus making inappropriate the use of the average crustal abundance of aluminum $(8.2 \%)$ to estimate \% Min. This must be verified by estimating the quartz fraction of SPM in future work. In contrast to flood tides, the 3-component model applied to SPM collected at the mouth on ebb tides did account for $100 \%( \pm 1 \sigma)$ of the SPM in spring (insufficient data in fall), and the assessed composition was reasonably like that of riverine SPM in spring (Table 2). Biogenic silica enrichment on flood tides near the mouth in both fall and spring (Table 2) suggested that diatoms, or at least their frustules, are abundant in coastal waters off the Columbia River mouth during these seasons.

\section{POC and chlorophyll content of estuarine SPM}

For estuarine surface water at Buoy 39 and river water at RM53, \% POC displayed a linear relationship with 1/SPM in all 3 seasons (fall 1990: \% POC $=35.0 \times$ $1 / \mathrm{SPM}+1.3, \mathrm{r}^{2}=0.90$, Fig. 4A; summer 1991: \% POC $=$ $83.2 \times 1 / \mathrm{SPM}+0.60, \mathrm{r}^{2}=0.82$, not shown; and spring 1992: \% POC $=104.5 \times 1 / \mathrm{SPM}+0.98, \mathrm{r}^{2}=0.75$, Fig. 4B) The regression lines fitting these data share a common intercept statistically and differ only in slope, reflecting the seasonality of the POC:SPM relationship. Binary mixing of 2 well-defined source materials could account for the seasonal change in slope (Morris et al. 1987). One source could be organic-poor material of temporally fixed composition, and the other organic- rich material of seasonally variable composition. $\%$ POC measured in ETM and other near-bottom particles was almost always higher than predicted by the apparent seasonal mixing lines for particles in surface waters, and estuarine surface waters tended to have lower SPM concentrations (higher 1/SPM values) than river water on many occasions (Fig. 4A, B). These 2 observations suggest that a significant fraction of riverborne SPM is removed by some sedimentary process within the estuary, and that near-bottom estuarine waters in the region of ETM are a POC trap, with some of this $\mathrm{POC}$ originating from the river.

The ratio of chlorophyll a to POC (chl/POC in $\mathrm{mg} \mathrm{g}^{-1}$ ) plotted as a function of 1/SPM indicates the dearth of chlorophyll $a$ in all particles from the central estuary in fall 1990 (Fig. 5A). Chl/POC values in the river averaged higher in late September than 2 wk later in October, indicating that the organic matter composition of the river was shifting from its summer to fall character. Chl/POC values in ETM particles were lowest of all, suggesting that POC trapped in ETM in the fall had a long enough residence time for its chlorophyll content to be reduced to about half that of estuarine surface waters, on average. In spring (Fig. 5B), a large phytoplankton bloom characterized by very high chl/POC ratios appeared in the river. Estuarine surface waters also showed particles with very high chl/POC ratios, but often at larger 1/SPM values (lower SPM concentrations) than in the river. Chl/POC ratios in ETM were lower, but still within the range of healthy phytoplankton (Welschmeyer \& Lorenzen 1985). Thus in spring, settling phytoplankton appears to represent a major source of chlorophyll-rich organic matter for ETM. Mudflat-derived SPM had by far the lowest chl/POC ratios (Fig. 5B), suggesting that inputs from the flats in spring could depress chl/POC ratios in ETM. However, mudflat contribution was organic-poor and mineralrich in spring (Table 2, Figs. 2 \& 4B), suggesting that 

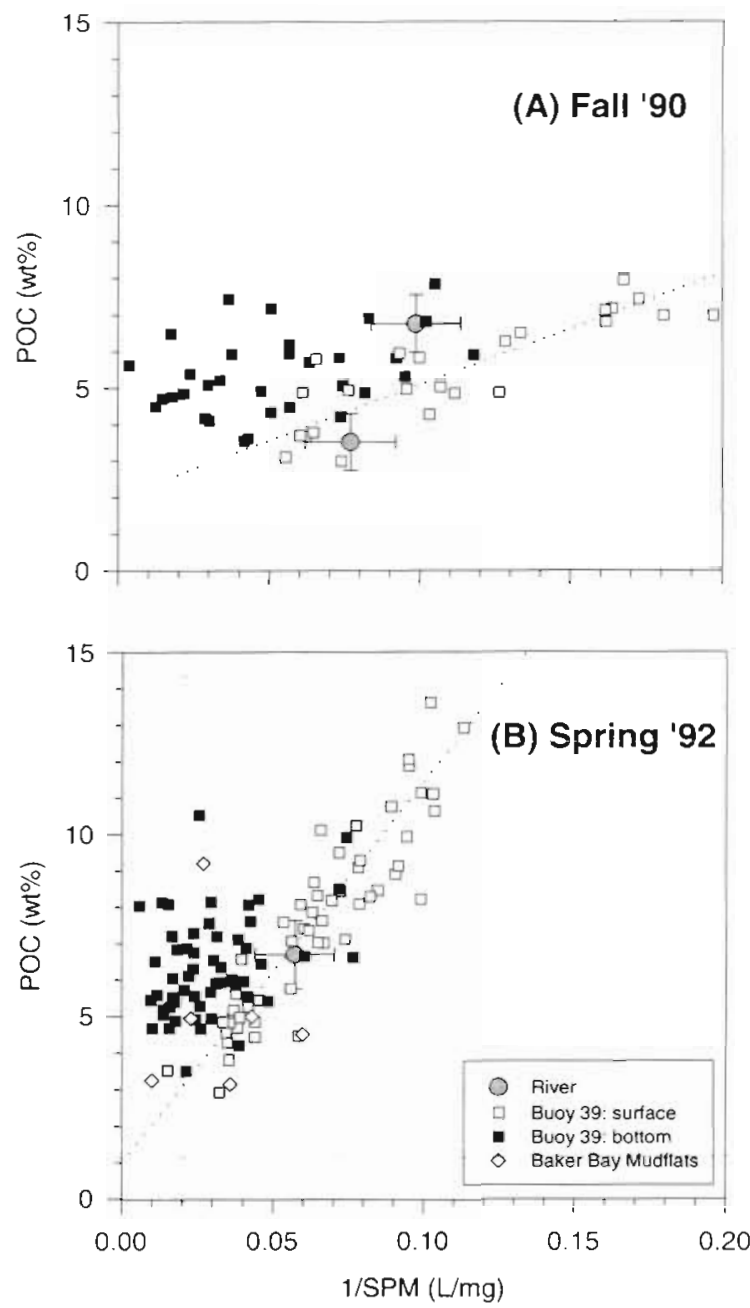

Fig. 4. POC as a weight percentage of SPM (\% POC) plotted as a function of 1/SPM in (A) fall 1990 and (B) spring 1992.\% POC averages higher in ETM particles than predicted by the implied binary mixing line for SPM in surface waters (see sloping dotted lines). Statistics for the sloping dotted mixing lines fitted by simple linear regression analysis of data for surface water SPM are given in the text. The area of the plot to the left of the vertical dotted line depicts ETM $\left(\geq 50 \mathrm{mg} \mathrm{SPM}^{-1}\right.$ )

inputs to ETM were insufficient to override the influence of sources with high \% POC (Fig, 4B). Significant mudflat input has been documented for ETM in other macrotidal, river-dominated estuaries (Dupont et al. 1994), so we cannot at this time discount its effect over all seasons for Columbia ETM.

The coastal ocean is also a potential source of POC to mid-estuarine ETM; thus, \% POC was investigated as a function of $1 /$ SPM near the mouth of the estuary (RM10; Fig. 1) during a period of neap tides. Particles from RM10 presented a more complex compositional picture (Fig, 6A, B) than those from upriver or in ETM at Buoy 39. Flood tides in fall (Fig, 6A) introduced to the estuary very low SPM concentrations (i.e. high $1 / \mathrm{SPM}$ values) with high POC content. In contrast, ebb tides at this time generally flushed out somewhat higher SPM concentrations with lower POC content. This pattern suggests uncompensated SPM loss to the coastal ocean on ebb tides. However, the increased $\%$ POC from the ocean, in the face of organic-depleted SPM loss to the ocean, is consistent with the accumulation of POC in ETM and other near-bottom waters of the central estuary (Fig. 4A).

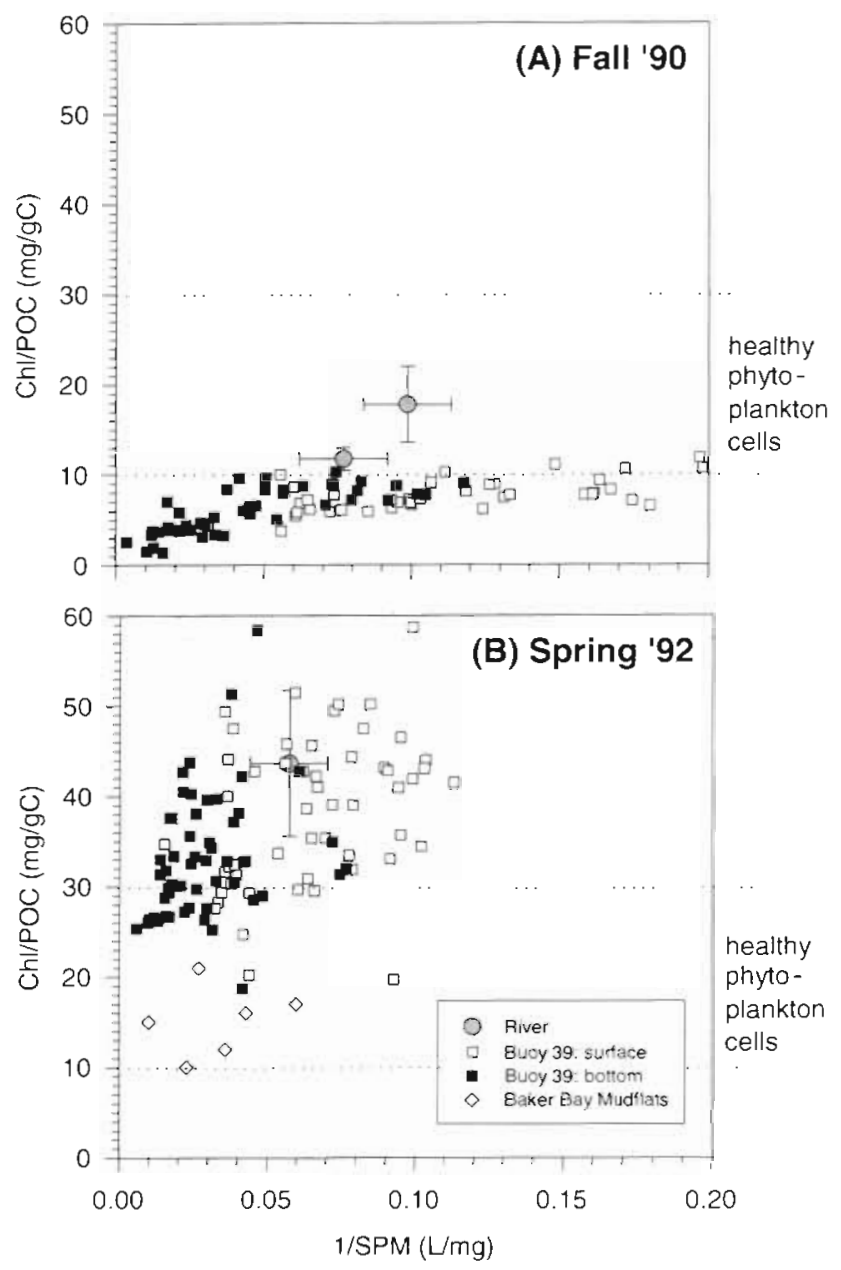

Fig. 5. The ratio of chlorophyll a to $\mathrm{POC}$ (chl/POC) plotted as a function of 1/SPM. The average range of chl/POC for healthy phytoplankton cells values (Welschmeyer \& Lorenzen 1985 ) is indicated by the horizontal dotted lines. (A) Note the dearth of chlorophyll a for all estuarine SPM in the fall, especially for particles concentrated in ETM. Values for chl/POC measured in riverine SPM from September plotted higher than those from October, indicating that riverine POC was changing from its summer to fall character. (B) In spring, a large phytoplankton bloom in the river carried through to estuarine surface waters and apparently transferred stillhealthy cells to the bottom. The area on the plots to the left of the vertical dotted line depicts ETM $\left(\geq 50 \mathrm{mg} \mathrm{SPM}^{-1}\right)$ 

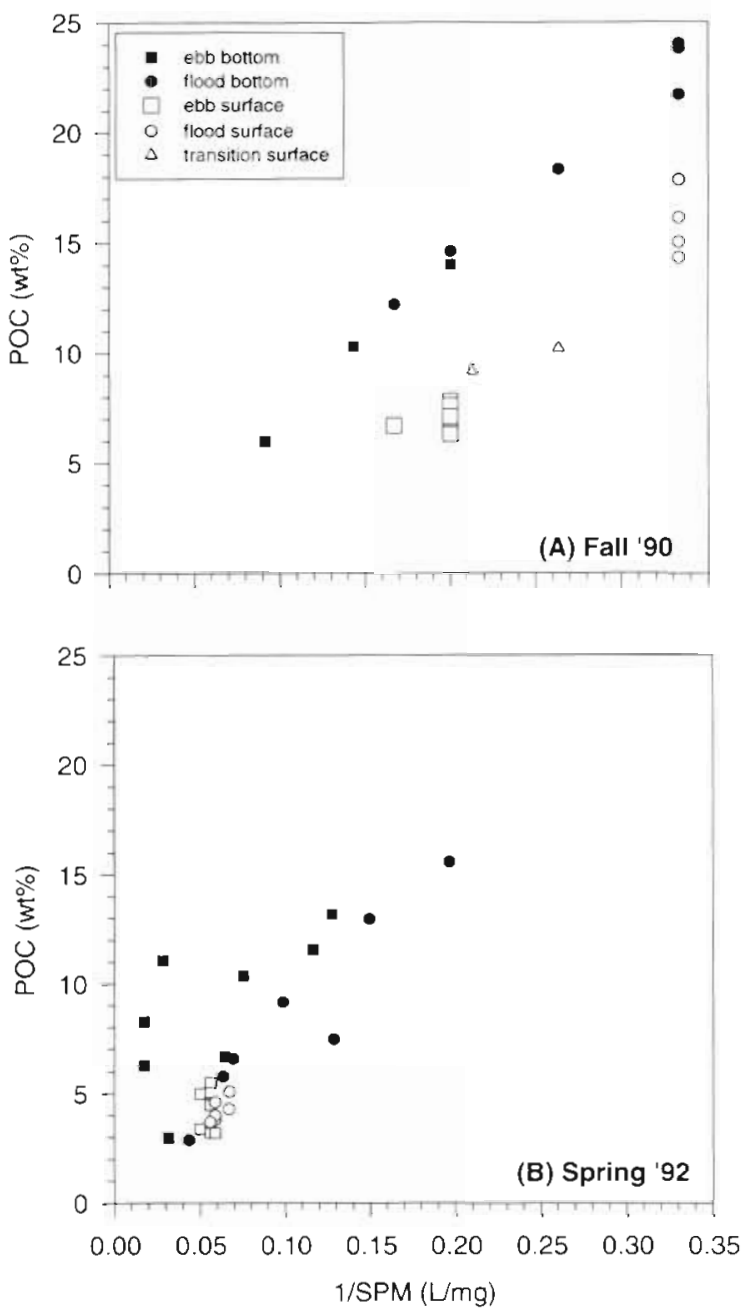

Fig. 6. \% POC plotted as a function of 1/SPM for samples collected near the mouth of the estuary on ebb and flood tides from both surface and near-bottom waters. (A) In fall, \% POC displays 2 different direct relationships that are dependent on the depth of SPM collection but independent of tidal phase at the time of collection. (B) In spring, \% POC measured in particles collected near bottom during ebb tides averaged greater than that for all other samples (which appear to conform to a common direct relationship). The area on the plots to the left of the vertical dotted line depicts ETM $(\geq 50 \mathrm{mg}$ SPM $l^{-1}$ )

There is seasonality to SPM concentrations and $\%$ POC at RM10. In spring (Fig. 6B) SPM concentrations averaged higher and \% POC lower than in fall (Fig. 6A) on both flood and ebb tides, and particularly at the surface. \% POC in near-bottom waters on the ebb tide (Fig. 6B) lies well within the range of values characteristic of ETM in mid-estuary (Fig. 4B), suggesting an ETM source for the RM10 particles in spring. Strong ebbing conditions (associated with spring tides in particular) likely lead to significant ero- sion of particles from ETM out to sea, thereby controlling the turnover time for particles concentrated in these transient sedimentary features of the estuary.

It seemed likely that if the coastal ocean was to be a source of POC to mid-estuarine ETM in spring, the near-bottom flood tide would be the main delivery vehicle. Furthermore, the \% POC signature of the flood might be different from that of fall floods, and thereby yield information on the relative seasonal importance of floods to the organic component of ETM. We plotted \% POC derived from the near-bottom flood at RM10 as a function of 1/SPM in both spring and fall, and compared these results with averages ( $\pm 1 \sigma$ ) observed for surface waters from the river-estuary continuum (Fig. 7). Data for RM10 in both fall and spring described a single tight linear relationship $\left(\% \mathrm{POC}=65.5 \times 1 / \mathrm{SPM}+1.52, \mathrm{r}^{2}=0.97\right)$ over a range of SPM concentrations spanning 1 order of magnitude ( 3 to $25 \mathrm{mg} \mathrm{l}^{-1}$ ). The slope of this relationship lies midway between those for corresponding surface water regressions at mid-estuary (Buoy 39) in spring and fall, while the $y$-intercepts are all comparable $(1.0 \pm 0.35)$. Although more data are needed, these observations suggest that \% POC as a function of SPM concentration in near-bottom ocean-source water varies little, whereas the relationship between riverine POC and SPM has a pronounced seasonal dependence

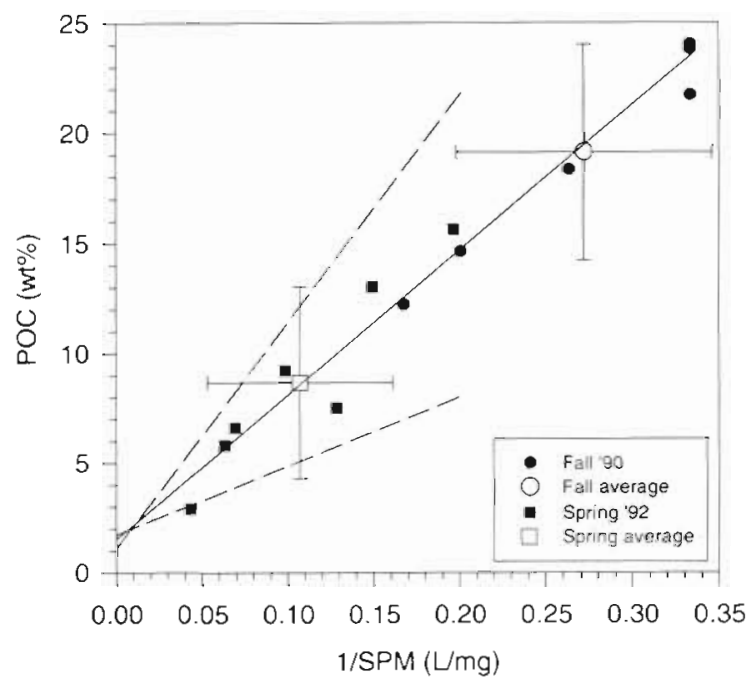

Fig. $7 \%$ POC plotted as a function of 1/SPM in near-bottom water on the flood tide only, presuming near-bottom flood waters are the most likely direct input of SPM from the coastal ocean to ETM. Note the lack of seasonality, even though the fall and spring averages $( \pm 1 \sigma$ ) do not overlap. The regression lines for estuarine surface waters from fall 1990 and spring 1992 (from Fig. 4A, B) are also plotted (dashed lines) for comparison. The area on the plot to the left of the vertical dotted line depicts ETM ( $\geq 50 \mathrm{mg} \mathrm{SPM}^{-1}$ ) 
Chl/POC values measured in particles at RM10 showed relationships to $1 / \mathrm{SPM}$ during both fall and spring (not illustrated) similar to those observed for the river-estuary continuum in those seasons (Fig. 5A, B), with one specific exception. In fall, all chl/POC ratios measured at RM10 in particles from both surface and near-bottom waters were about double those ratios for the central estuary. This result indicates not only that the relatively small amount of SPM brought into the estuary from offshore in fall is rich in POC (Fig. 7), but that the POC is rich in chlorophyll a.
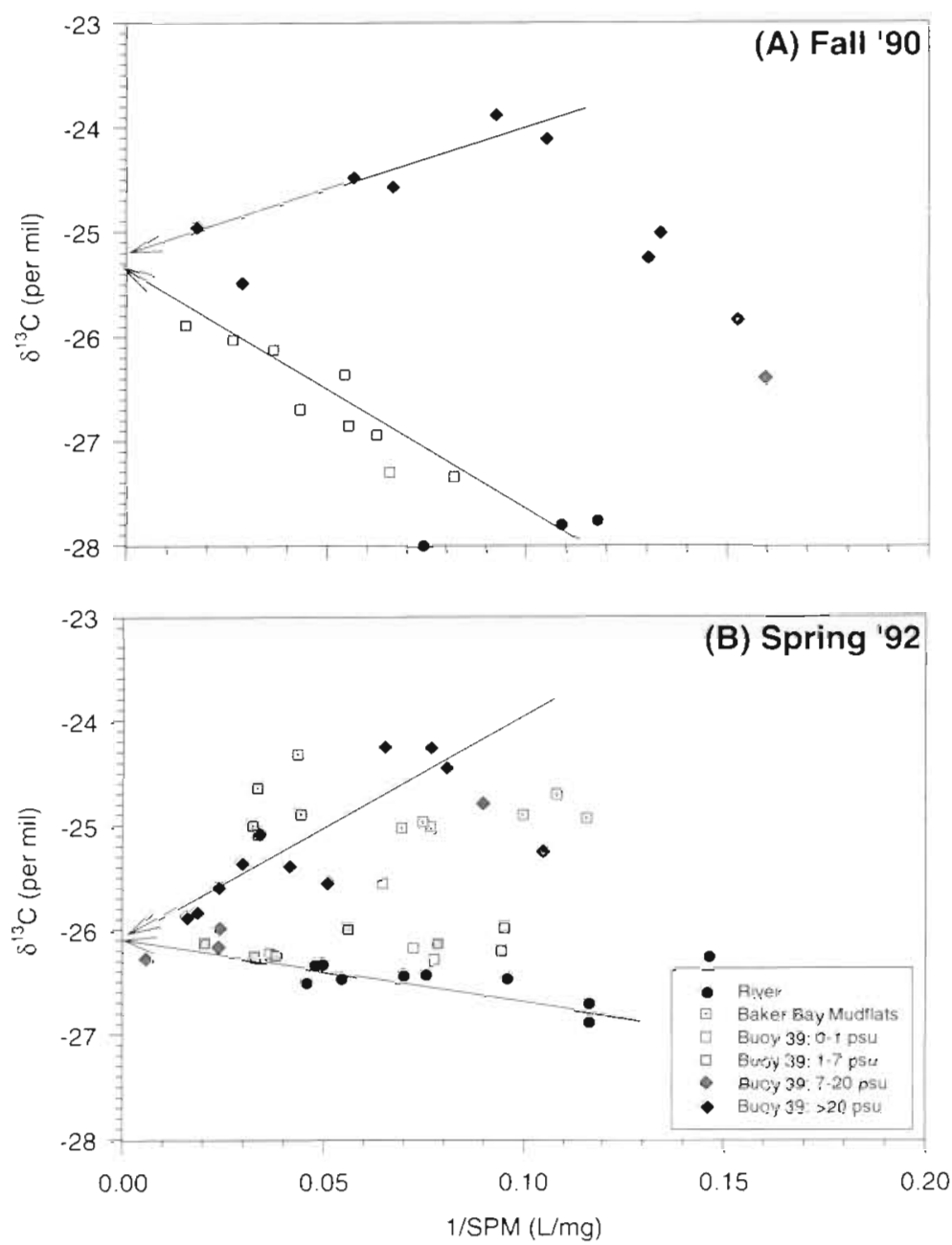

Fig. $8 . \delta^{13} \mathrm{C}$ of POC plotted as a function of $1 / \mathrm{SPM}$ in (A.) fall 1990 and (B) spring 1992. The isotoplc composition of riverborne POC varies seasonally between -28 and $-26.5 \%$ and becomes progressively ${ }^{13} \mathrm{C}$-enriched as salinity and SPM concentration increase in the estuary. POC from high-salinity source water in the estuary, on the other hand, starts out much more ${ }^{13} \mathrm{C}$-enriched $\left(\hat{\sigma}^{13} \mathrm{C}>-24 \%\right)$ and becomes progressively more ${ }^{13} \mathrm{C}$-depleted as SPM concentration increases. These 2 trends project in the case of fall 1990, summer 1991 (data not shown) and spring 1992 toward a relatively constant $\delta^{13} \mathrm{C}$ composition of -26 to $-25.5 \%$ for POC concentrated in ETM. The area on the plots to the left of the vertical dotted line depicts ETM ( $\left.\geq 50 \mathrm{mgS} \mathrm{SPM} \mathrm{l}^{-5}\right)$

\section{Isotopic composition of POC}

POC in riverborne SPM (RM53) was the most ${ }^{13} \mathrm{C}$-depleted of any analyzed in the river-estuary continuum. with $\delta^{13} \mathrm{C}$ values varying seasonally between -28 and $-26.5 \%$ (Fig. 8A, B). POC in SPM collected near the mouth of the estuary (RM10) in waters of salinity $\geq 30 \mathrm{psu}$ was most ${ }^{13} \mathrm{C}$-enriched, with $\delta^{13} \mathrm{C}$ values averaging $-20.3 \pm 0.8 \%$ (not illustrated). Within the estuary at Buoy 39, POC from freshest waters displayed progressive ${ }^{13} \mathrm{C}$-enrichment as SPM concentration increased, while that from clearest water of highest salinity ( $>20$ psu on the flood tide) displayed progressive ${ }^{13} \mathrm{C}$-depletion as SPM concentration increased. The same isotopic trends were observed in all seasons, converging on a relatively constant $\delta^{13} \mathrm{C}$ composition between -26 and $-25.5 \%$ for POC concentrated in ETM. These observations reinforce the importance of the river as a major source of POC concentrated in ETM, but also indicate that some degree of transformation or addtional source contribution is required to account for the carbon isotopic composition of organic matter concentrated in this transient sedimentary feature. POC advecting during an ebb tide of Baker Bay mudflats, near the mouth of the estuary (Fig. 1), displayed a $\delta^{13} \mathrm{C}$ of approximately $-25 \%$ in spring, over SPM concentrations less than in ETM (Fig 8B). Whether mudflat $\delta^{13} \mathrm{C}$ values converge on $-26 \%$ in higher SPM concentrations in spring, as estuarine and riverine $\delta^{13} \mathrm{C}$ values do, is as yet unknown.

\section{Lignin biomarker composition of POC}

The lignin and chlorophyll a content (both normalized to organic carbon) of SPM from the river, estuary, and Baker Bay mudflats were compared in an effort to differentiate the relative contribution of POC from vascular plant and phytoplankton sources, respectively (Fig. 9), Lignin content generally increased as chl/POC values decreased in the estuary. Recognizing that lowest chl/POC values in the central estuary are typically associated with fall ETM (Fig. 5A), the trend depicted in Fig. 9 suggests that POC concentrated in fall ETM is the most enriched in vascular plant debris. Thus, a reasonable fraction of the enhanced POC concentrations in ETM in the fall (Fig. 4A) could be due to increased input of vascular plant 


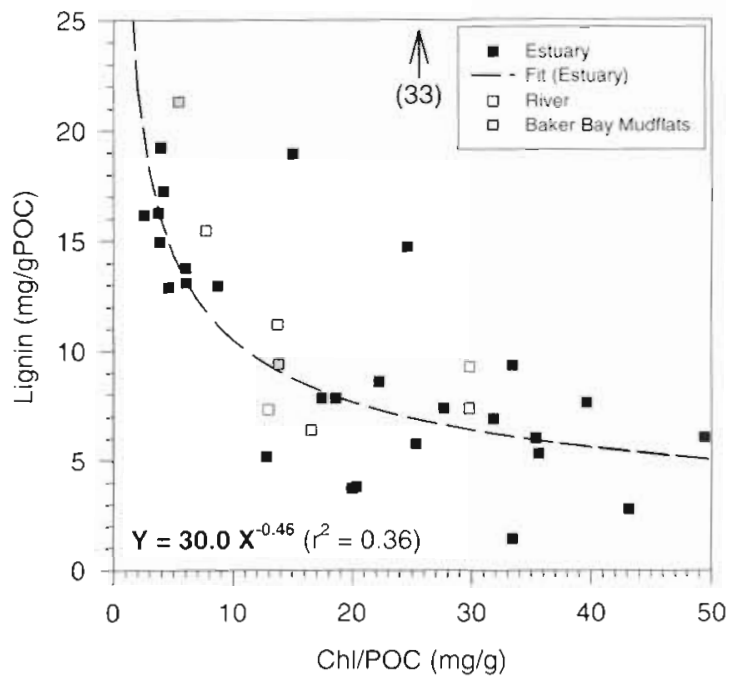

Fig. 9. Lignin content of POC plotted as a function of chl/POC composition. At lowest chl/POC values, characteristic of ETM (Fig. 5), lignin content tends to be highest. This trend suggests the POC content of ETM contains a greater contribution of organic matter from vascular plant relative to phytoplanktonic sources than does that of surface and other non-ETM waters. Note that POC from intertidal mudflats has a high lignin content like that of ETM

debris at this time. Some of this input probably originates from mudflats, as POC from mudflat outwash is higher in lignin content and lower in chlorophyll than ETM (Fig. 9). Conversely, spring ETM have high chl/ POC ratios (Fig. 5B), and these are associated with relatively low lignin/POC ratios (Fig. 9), indicative of an enhanced phytoplankton and reduced vascular plant content.

Detailed examination of compositional data for lignin phenols affords a potentially more quantitative way to assess the contribution of vascular plant sources to POC in SPM. Ertel \& Hedges (1985) formulated the ratio of vanillic acid to vanillin ([Ac/Al] $]_{v}$ ) as an index for the degradation state of lignin in environmental samples analyzed by $\mathrm{CuO}$ oxidation. Fungally degraded forms of vascular plant material like that contained in soil typically show significantly higher $[\mathrm{AC} / \mathrm{All}]_{v}$ values $(>0.2)$ than do the fresh vascular plant materials $(0.1$ to 0.2 ) that contribute to soils (Hedges et al. 1988). In Fig. 10, lignin phenol yields for various sediments collected behind major dams throughout the Columbia River drainage basin (Prahl et al. 1994) are plotted versus $[\mathrm{Ac} / \mathrm{Al}]$, values measured in corresponding samples. Although the presence of autochthonous organic matter cannot be discounted absolutely, Prahl et al. (1994) have argued using a variety of organic geochemical constraints that the organic matter contained in these bottom sediments from the Columbia River is predominantly derived from soils and vascular plants.
A trend of decreasing lignin yield with increasing [Ac/Al] is apparent in these Columbia River sediments (Fig. 10). Although quantitatively offset, the trend is reminiscent of changes in lignin composition of birchwood as it is degraded progressively by fungi under controlled laboratory conditions (Hedges et al. 1988). Notably, the lignin composition of organic carbon associated with fine and coarse-grained SPM isolated from the Amazon River (Hedges et al. 1986) and with soils from a coniferous forest from the Willamette River basin (Prahl et al. 1994) also plot along the trajectory of the apparent trend for Columbia sediments (Fig. 10). Assuming the dashed curve empirically fitted to data for the Amazon and all bottom sediments from the Columbia River $\left(\right.$ Lignin $=3.96 \times[\mathrm{Ac} / \mathrm{Al}]_{v}{ }^{-187}, \mathrm{r}^{2}=$

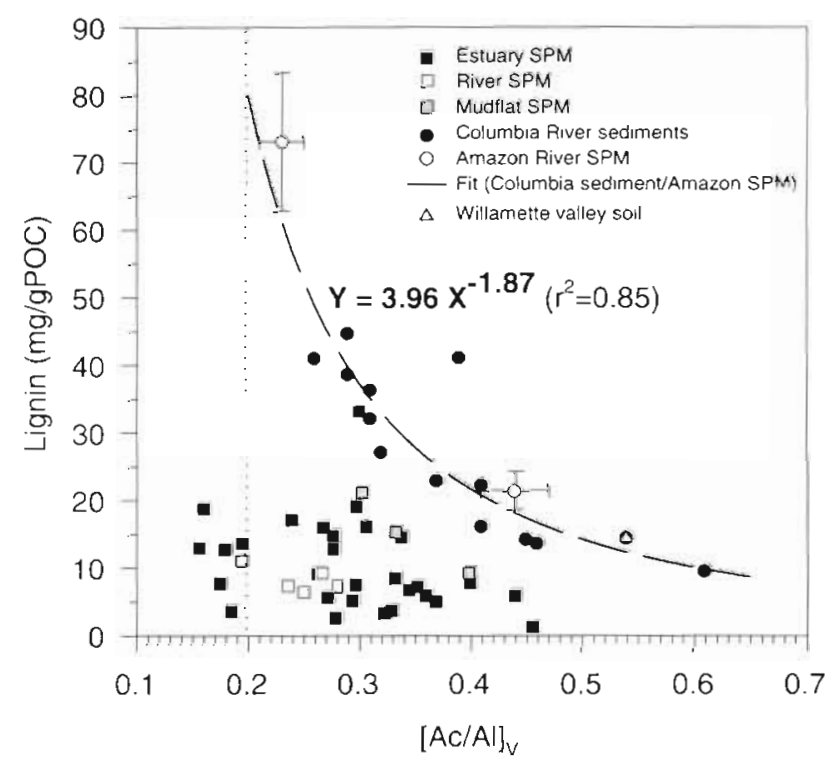

Fig. 10. Lignin concentration ( $\mathrm{mg} \mathrm{g}^{-1}$ POC) plotted as a function of values for the ratio of vanillic acid to vanillin ([AC/AI $]_{v}$ ). $\left[A c / A_{A} \mid\right]_{v}$ is an index for the degradation state of lignin in vascular plant debris, with more degraded forms displaying higher values of this ratio than fresh vascular plants 0.1 to 0.2. Ertel \& Hedges 1985). All data for SPM from the Columbia River estuary plot below a presumed calibration curve for pure allochthonous organic matter introduced erosionally to the river drainage. The dashed curve is defined from an empirical fit of compositional data for lignin analyzed in sediments collected throughout the mainstem Columbia (Prahl et al. 1994) and SPM collected from the Amazon (Hedges et al. 1986) drainage basins, respectively. Compositional data for lignin analyzed in soils from a coniferous forest in the Willamette Valley (northwestern USA) (Prahl et al. 1994) also fit the curve. The systematic deviation of data for SPM from the Columbia River and its estuary from the presumed calibration line suggests that allochthonous sources of organic matter such as leaf litter and soils were not major contributors to organic matter in SPM from the river and estuary, but they were generally more important in material eroding off intertidal mudflats. Vertical dotted line depicts the upper value for $[\mathrm{Ac} / \mathrm{Al}]_{v}$ typically measured in fresh vascular plant tissues 


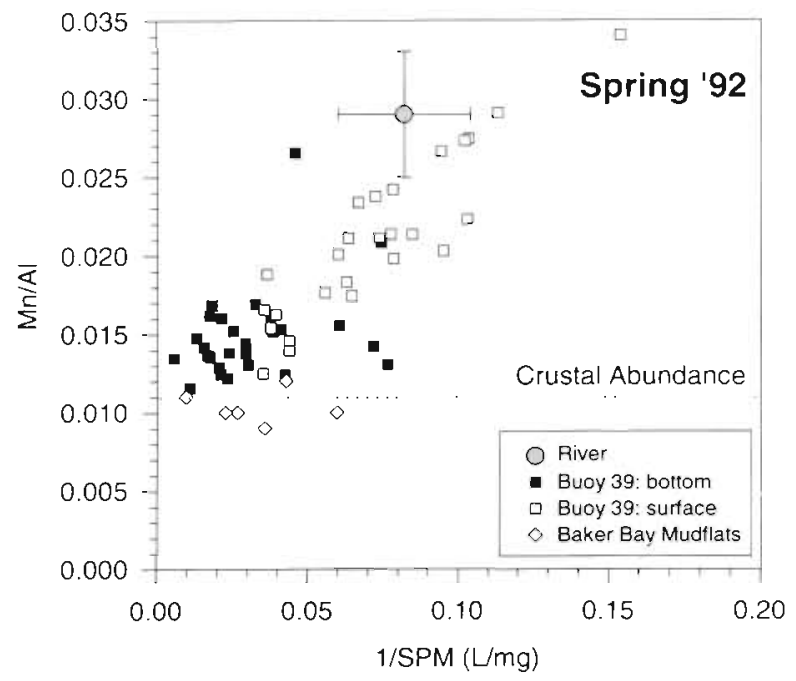

Fig. 11. Ratio of total particulate manganese to aluminum (Mn/Al) plotted as a function of $1 / \mathrm{SPM}$ in spring 1992. Mn/Al values decline systematically from the river to the estuary, with lowest values approaching crustal abundance ( 0.011) in ETM. Mn/A] ratios measured in particles advecting off intertidal mudflats are also at crustal abundance, suggesting such peripheral settings in the estuary are a direct source of particles to ETM. The $\mathrm{Mn} / \mathrm{Al}$ dataset for summer 1991 which shows all of these same features has been published elsewhere (see Fig. 5 in Prahl \& Coble 1994). The area on the plot to the left of the vertical dotted line depicts ETM ( $\geq 50 \mathrm{mg} \mathrm{SPM} \mathrm{l}^{-1}$ )

$0.85)$ represents the composition of pure land-derived organic matter, the significant deviations from this curve observed in our present study for SPM from the river, estuary and mudflats (Fig. 10) can be ascribed to dilution with organic carbon from a lignin-free biological source such as riverine phytoplankton. If such interpretation of Fig. 10 is correct, then we can conclude that organic matter from allochthonous sources such as leaf litter and soil were not dominant contributors to POC within the Columbia River and its estuary most of the time. This is in agreement with the positive correlation be:ween autochthonous primary production (i.e. \% BSi) and \% OM (Fig. 3).

Data for SPM eroding off the intertidal mudflats in the Columbia system plot closest to the dashed curve in Fig. 10. This again suggests that SPM from mudflats is the most enriched in vascular plant debris of any we have analyzed to date from the Columbia River and its estuary. In addition to lignin composition, there is further evidence of mudflat influence on ETM from the ratio of total particulate manganese to aluminum $(\mathrm{Mn} / \mathrm{Al})$ in the detrital mineral fraction of SPM. This ratio declined systematically from the river to the estuary, with the lowest values observed typically in ETM and approximating crustal abundance ( 0.011; Fig. 11). Assuming the $\sim 3$-fold excess of $\mathrm{Mn}$ above crustal abundance observed in riverborne SPM reflects the presence of a reducible $\mathrm{MnO}_{2}$ phase, apparent absence of this phase in ETM would require passage of the particle through a low-oxygen environment (Froelich et al. 1979) somewnere within the estuary. Intertidal mudflats would provide just such an environment. Perhaps it is not coincidental that SPM eroding from the mudflats, stripped to its crustal abundance for Mn, is close to the composition observed for particles concentrated in ETM (Fig. 11).

\section{DISCUSSION}

Dahm et al. (1981) showed from their study in 1973-74 that total organic carbon concentration in the Columbia River (averaging $89 \%$ DOC, $11 \%$ POC) peaked during late spring and early summer and was at a minimum in late fall. Subsequent study of the Columbia River estuary in the early 1980s (Small et al. 1990) demonstrated that this seasonal pattern not only applied to detrital and phytoplanktonic POC concentrations in the river, but translated into the estuary as well. Furthermore, transport rates of phytoplanktonic POC from the river to the mouth of the estuary followed the same seasonal pattern (Lara-Lara et al. 1990b). Given this descriptive background, Lara-Lara et al. (1990a) then suggested that healthy freshwater phytoplankton introduced fluvially to the estuary lyse and sink out of surface waters when exposed to salinities of -2 to 5 psu. Our current results more clearly define riverine contribution of particles to the estuary and ETM and build upon these prior generalizations.

For example, our results show that estuarine surface waters typically become less turbid than river water (Fig. 4). This condition requires that some component of riverine SPM be removed within the estuary by sedimentation. Presumably, this sedimentary removal process enriches the ETM with particles of relatively high POC content. The latter inference derives from our observation that \% POC values for particles in ETM and in non-ETM bottom waters in all seasons are consistently and significantly higher than predicted from mixing relationships devised for \% POC in surface waters in the central estuary (Fig. 4) and in bottom waters entering the mouth of the estuary on flood tides (Fig. 7). POC enrichment in ETM points to this transient sedimentary feature as an effective trap of organic-rich particles.

Baross et al. (1994) showed high metabolic activity of bacteria and greatly elevated concentrations of protozoa and copepods in ETM. This discovery suggested that ETM are important sites for enhanced 'microbial loop' activity and higher-order trophic dynamics. Such concentrated biological activity in ETM may reach its 
zenith in the springtime given our evidence that the chl/POC composition of ETM is synchronized on a seasonal basis with that of the river. High $\mathrm{chl} / \mathrm{POC}$ ratios evident in the spring are viewed as indicative of an abundance of healthy phytoplankton cells, which when entrained into ETM are then presumably available for direct grazing by zooplankton (Simenstad et al. 1994a) and perhaps for indirect use by bacteria as the cells lyse and release DOM (Baross et al. 1994).

$\delta^{13} \mathrm{C}$ data also identified ETM as a POC trap, and suggested that organic matter introduced by the river, the coastal ocean, and perhaps the adjacent mudflats helps to maintain the composition of this trap. Convergence on a common isotopic signature for ETM particles $(-26$ to $-25.5 \%$ ), when the apparent source terms have such disparate $\delta^{13} \mathrm{C}$ signatures, strongly suggests mixing and eventual accumulation of particles on or near the bottom in the region of ETM. Our data, albeit limited, shows there is little if any seasonal change in the ultimate isotopic composition of POC concentrated in the ETM. This evidence, along with some based on interpretation of \% POC data, suggests that ETM are regulated at a relatively steady-state composition by source contributions in concert with internal biological transformation processes.

We still have no unequivocal way to quantify the relative contribution of $\mathrm{POC}$ from the presumed sources to ETM. Predominance of one source over the other is dictated by the total amount of SPM delivered to ETM regions of the estuary from each source, with seasonal adjustment via changes in the \% POC of SPM from each source. Given that river input is more or less continuous with recognized seasonal variations in amplitude, while tidal input from the coastal ocean to the estuary is intrinsically periodic, the river would always seem to be the major source of POC. Rapid riverine input to ETM during spring phytoplankton blooms is evidenced by greatly elevated chl/POC ratios in ETM (Fig. 5B), but high chl/POC ratios do not necessarily signify high POC concentrations. Similarly, \% OM in SPM of bottom flood water at the mouth of the estuary in fall was extremely high $(35 \%)$ relative to that in riverborne SPM (12\%) (Table 2 ), and chl/POC values at the mouth in fall (not illustrated) were nearly double those of river and mid-estuary waters at the same time (Fig. 5A). At face value, these observations might suggest an increased importance of the coastal ocean as a source of POC to ETM in fall. However, major seasonal variations in the relative proportion of source contribution from the river and the sea seems in conflict with the constancy of $\delta^{13} \mathrm{C}$ composition documented in ETM by our datasets for spring, summer (data not shown) and fall (Fig. 8).

The quantitative role of intertidal mudflats as contributors of SPM and POC to ETM is also unknown at this time. To date, 2 lines of geochemical evidence support the possibility of intertidal mudflat contribution. First, SPM eroding from intertidal mudflats contained POC relatively enriched in lignin and depleted in chlorophyll a content. Both attributes are compositional features consistent with salient characteristics of particles concentrated in ETM. Second, Mn/Al ratios measured on mudflat SPM and on particles concentrated in ETM are essentially at crustal abundance $(\sim 0.011)$ and significantly lower than ratios characterizing riverine SPM $(\sim 0.03)$. Neither piece of evidence proves major mudflat contribution to the ETM; in fact, the small \% OM values relative to those in the river and estuary, at least in spring (Table 2), suggest minimal contribution of organic matter. However, relatively high \% Min values (Table 2), in concert with the crustal $\mathrm{Mn} / \mathrm{Al}$ ratios (Fig. 11), argue for appreciable input of detrital minerals to ETM. Careful consideration of riverine, coastal and mudflat contributions must still be given in developing numerical models to describe the ecological significance of particle dynamics in estuarine systems like the Columbia River.

Acknowledgements. We are grateful to Dr Daniel Conley for performing the biogenic silica determinations while resident at Horn Point Environmental Laboratory, and to Sandy Moore, Stacey Morgan and Margaret Sparrow for expert assistance on board ship and in the laboratory. We also thank our other colleagues in the Columbia River LMER program as well as the crew of RV 'Robert Gordon Sproul', without whose collaboration and interest this work would not have been possible. We are indebted to the National Science Foundation for financial support of this work (OCE-94120281).

\section{LITERATURE CITED}

Amspoker MC, Mclntire CD (1986) Effects of sedimentary processes and salinity on the diatom flora of the Columbia River Estuary. Bot Mar 29:391-399

Baross JA, Crump B, Simenstad CA (1994) Elevated 'microbial loop' activities in the Columbia River estuary turbidity maximum. In: Dyer $\mathrm{K}$, Orth $\mathrm{R}$ (eds) Changing particle fluxes in estuaries: implications from science to management. ECSA22/ERF Symposium. Olsen \& Olsen Press, Friedensborg, p 459-464

Berner EK, Berner RA (1996) Marginal marine environments: estuaries. In: Global environment: water, air and geochemical cycles, Chap 7. Prentice Hall, Englewood Cliffs, NJ, p 284-311

Bristow MPF, Bundy DH, Edmonds CM, Ponto PE, Frey BE, Small LF (1985) Airborne laser fluorosensor survey of the Columbia and Snake rivers: simultaneous measurements of chlorophyll, dissolved organics and optical attenuation. Int J Remote Sens 6:1707-1734

Collier R (1991) Analysis of particulate matter collected by sediment traps and from sediment cores. In: Hurd DC, Spencer DW (eds) Marine particles: analysis and characterization. Geophysical Monograph 63, American Geophysical Union, Washington, DC, p 235-242

Dahm CN, Gregory SV, Park PK (1981) Organic carbon trans- 
port in the Columbia River. Estuar Coast Shelf Sci 13: $645-658$

DêAaster DM (1981) The supply and accumulation of silica in the marine environment. Geochim Cosmochim Acta 45: $1715-1732$

Dupont JP, Lafite R, Huault MF, Hommeril P, Meyer R (199i) Continental/marine ratio changes in suspended and settled matter across a macrotidal estuary (the Seine Estuary, northwestern France). Mar Geol 120:27-40

Ertel JR, Hedges JI (1985) Sources of sedimentary humic substances: vascular plant debris. Geochim Cosmochim Acta 49:2097-21.07

Froelich PN, Klinkhammer GP, Bender ML, Luedtke NA. Heath GR, Cullen D, Dauphin P. Hammond D, Hartman B, Maynaard V (1979) Early oxidation of organic matter in pelagic sediments of the eastern equatorial Atantic: suboxic diagenesis. Geochim Cosmochim Acta 43:1075-1090

Gelfenbaum G (1983) Suspended-sediment response to semidiurnal and fortnightly tidal variations in a mesotidal estuary: Columbia River, U.S.A. Mar Geol 52:39-57

Geyer WR (1993) The importance of suppression of turbulence by stratification on the estuarine turbidity maximum. Estuaries $16 \cdot 113-125$

Hayes JM. (1983) Practice and principles of isotopic measurements in organic geochemistry. in: Meinshein WG (ed) Organic geochemistry of contemporameous and ancient sediments, p 5-1-5-31

Hedges JI, Blanchette RA, Welıky K, Devol AH (1988) Chemical effects of wood degradation by fungi: a controlled laboratory study. Geochim Cosmochim Acta 52:2717-2726

Hedges JI, Clark WA, Quay PD, Richey JE, Devol Ali, Santos $\mathrm{U}$ de $\mathrm{M}$ (1986) Compositions and fluxes of particulate organic material in the Amazon River Limnol Oceanogr $31: 717-738$

Hedges JI, Ertel JR (1982) Characterization of Iignin by gas capillary chromatography of cupric oxide oxidation products. Analyt Chem 54:174-178

Jay DA, Giese BS, Sherwood CR (1990) Energetics and sedimentary processes in the Columbia River Estuary. Prog Oceanogr 25:157-174

Lara-Lara JR, Frey BE, Small LF (1990a) Primary production in the Columbia River Estuary. I. Spatial and temporal variability of properties. Pacif Sci 44:17-37

Lara-Lara JR, Frey BE, Small LF (1990b) Primary production in the Columbia River Estuary. II. Grazing losses, transport, and a phytoplankton carbon budget. Pacif Sci 44 : $38-50$

Morris AW, Bale A.J, Howland RJ, Loring DH, Rantala RTT (1987) Controls of the chemical composition of particle populations in a macrotidal estuary (Tamar Estuary, U.K.) Cont Shelf Res 7:1351-1355

Prahl FG, Coble PG (1994) Input and behavior of dissolved organic carbon in the Columbia River Estuary. In: Dyer $K_{\text {, }}$ Orth R (eds) Changing particle fluxes in estuaries: impli-

Editorial responsibility: Peter Wangersky (Contributing Editor), Victoria, Britısh Columbia, Canada cations from science to management. ECSA22/ERF Symposium. Olsen \& Olsen Press, Fredensborg, p 451-457

Prahl FG, Ertel JR, Goni MA, Sparrow MA, Eversmeyer B (1994) Terrestrial organic carbon contributions to sedi. ments on the Washington margin. Geochim Cosmochim Acta 58:3035-3048

Rashid MA (1985) Geochemistry of marine humuc compounds. Springer-Verlag, New York

Reed DJ, Donovan J (1994) The character and composition of the Columbia River estuarine turbidity maximum. In: Dyer $\mathrm{K}$, Orth $\mathrm{R}$ (eds) Changing particle fluxes in estuaries: implications from science to management. ECSA22/ ERF Symposium. Olsen \& Olsen Press, Fredensborg, p $445-450$

Simenstad CA, Morgan CA, Cordell JA, Baross JA (1994a) Flux, passive retention, and active residence of zooplankton in Columbia River estuarine turbidity maxima. In: Dyer $\mathrm{K}$, Orth $\mathrm{R}$ (eds) Changing particle fluxes in estuaries: implications from science to management. ECSA22/ ERF Symposium. Olsen \& Olsen Press, Fredensborg, p $473-482$

Simenstad CA, Reed DJ, Jay DA, Baross JA, Prahl FG, Small LF (1994b) Land-margin ccosystcm rescarch in the Columbia River estuary: investigations of the couplings between physical and ecological processes within estuarine turbidity maxima. In: Dyer $K$, Orth $\mathrm{R}$ (eds) Changing particle fluxes in estuaries: implications from science to management. ECSA22/ERF Symposium. Olsen \& Olsen Press, Friedensborg, p 437-444

Simenstad CA, Small LF, McIntire CD, Jay D. . Sherwood, C (1990) Columbia River Estuary studies: an introduction to the estuary, a bnef history, and prior studies. Prog Oceanogr 25:1-13

Small LF, McIntire CD, Macdonald KB, Lara-Lara JR, Frey BE, Amspoker MC, Wintield T (1990) Primary production, plant and detrital biomass, and particle transport in the Columbia River Estuary. Prog Oceanogr 25:175-210

Small LF. Morgan SR (1994) Phytoplankton attributes in the turbidity maximum of the Columbia River Estuary. In: Dyer K, Orth R (eds) Changing particle fluxes in estuaries: implications from science to management. ECSA22/ ERF Symposium. Olsen \& Olsen Press, Fredensborg, $p$ $465-472$

Sullivan BE (1997) Annual cycles of organic matter and phytoplankton attributes in the Columbia and Willamette Rivers, with reference to the Columbia River Estuary. MSc thesis, Oregon State University, Corvallis

Taylor SR (1964) Abundance of chemical elements in the continental crust: a new table. Geochim Cosmochim Acta 28: 1273-1285

Welschmeyer $\mathrm{NA}$, Lorenzen CJ (1985) Chlorophyll budgets zooplankton grazing and phytoplankton growth in a temperate fjord and the Central Pacific Ocean. Limanol Oceanogr 30:1-21

Submitted: February 11, 1997; Accepted: October 20, 1997 Proofs received from author(s): December 8,1997 